\title{
BAKTERI RESISTEN ARSEN (As) PADA ALGA Padina australis DARI PERAIRAN KIMA BAJO
}

\author{
(Arsenic Resistant Bacteria on Brown Algae Padina australis \\ in The Waters of Kima Bajo)
}

\author{
Pratiwi Bone ${ }^{1}$, Desy M. H. Mantiri2 ${ }^{*}$, Kurniati Kemer ${ }^{2}$, Rizald M Rompas ${ }^{2}$, \\ Robert A. Bara ${ }^{2}$, Reiny A. Tumbol ${ }^{3}$
}

1. Mahasiswa Program Studi IImu Kelautan, FPIK UNSRAT Manado

2. Staf Pengajar Program Studi IImu Kelautan, FPIK UNSRAT Manado

3. Staf Pengajar Program Studi Budidaya Perairan, FPIK UNSRAT Manado

${ }^{*}$ Penulis korespondensi: Desy H.M. Mantiri; dmh mantiri@unsrat.ac.id

\begin{abstract}
Padina australis is a species of marine algae from the Phaeophyta division (brown algae) which is generally distributed in marine waters. This algae is able to live in waters with high levels of heavy metals such as in the Kima Bajo waters. This study aims to isolate arsenic (As)-resistant bacteria in $P$. australis, observe cell shape and bacterial characteristics, and determine bacterial resistance to antibiotics. The method used is conventional bacterial isolation which has been tested on $\mathrm{As}_{2} \mathrm{O}_{3}$ compounds. The results obtained were that $P$. australis contained arsenic resistant bacteria at concentrations of $250 \mathrm{ppm}, 500 \mathrm{ppm}$, and $1000 \mathrm{ppm}$. The bacteria obtained were Gram positive, in the form of bacilli. These arsenic-resistant bacteria are also resistant to antibiotics such as amoxicillin, cefixime, and doxycycline.
\end{abstract}

Keywords: Padina australis, Arsen (As), Kima Bajo

Alga laut jenis Padina australis merupakan spesies alga dari divisi Phaeophyta (alga cokelat) yang pada umumnya tersebar di perairan laut. Alga ini mampu hidup pada perairan dengan kadar logam berat tinggi. Penelitian ini bertujuan untuk mengisolasi bakteri resisten Arsen (As) pada alga $P$. australis, melihat bentuk sel dan karakteristik bakteri, serta melihat ketahanan bakteri terhadap antibiotik. Metode yang digunakan adalah isolasi bakteri secara konvensional yang telah diuji pada senyawa senyawa $\mathrm{As}_{2} \mathrm{O}_{3}$. Hasil yang diperoleh yaitu terdapat bakteri resisten arsen Gram positif dengan konsentrasi $250 \mathrm{ppm}, 500 \mathrm{ppm}$, dan $1000 \mathrm{ppm}$ pada alga $P$. australis serta bentuk sel bakteri adalah basil. Bakteri resisten arsen tersebut resisten juga terhadap antibiotik yaitu amoxicillin, cefixime, dan doxycycline.

Kata kunci : Padina australis, Arsen (As), Kima Bajo

\section{PENDAHULUAN}

Alga laut jenis Padina australis merupakan spesies alga dari divisi Phaeophyta (alga cokelat) yang pada umumnya tersebar di perairan laut, mulai perairan laut dangkal hingga perairan dalam. Alga ini memiliki bentuk lembaran yang lebar berwarna coklat transparan, warna cokelat karena di dalam thalusnya terkandung pigmen xantofil, yaitu fukosantin, selain fukosantin dan klorofil tersebut terdapat di dalam plastida (Sergiama, 2009).

$P$. australis telah diteliti memiliki manfaat antara lain antibakteri (Kemer, dkk, 2015;
Puasa, dkk. 2018). Logam yang masuk ke thalus alga dapat berasal dari sedimen dimaa alga tersebut hiidup walaupun logam berat ditemukan alga tersebut ditemukan tetap hidup dan bertumbuh sepanjang tahun (Mantiri et all 2019). Menurut penelitian Hidayat dkk 2021 terdeteksi ada beberapa logam berat yang terdapat pada thalus alga dan sedimen di perairan Kima Bajo.

Menurut Nontji (1993), ciri-ciri Padina australis adalah : Thallus berbentuk seperti kipas, membentuk segmen lembaran tipis a).Warna cokelat kekuningan, b). Bagian atas lobus agak melebar, c). Holdfast berbentuk cakram kecil berserabut (gambar 1). 


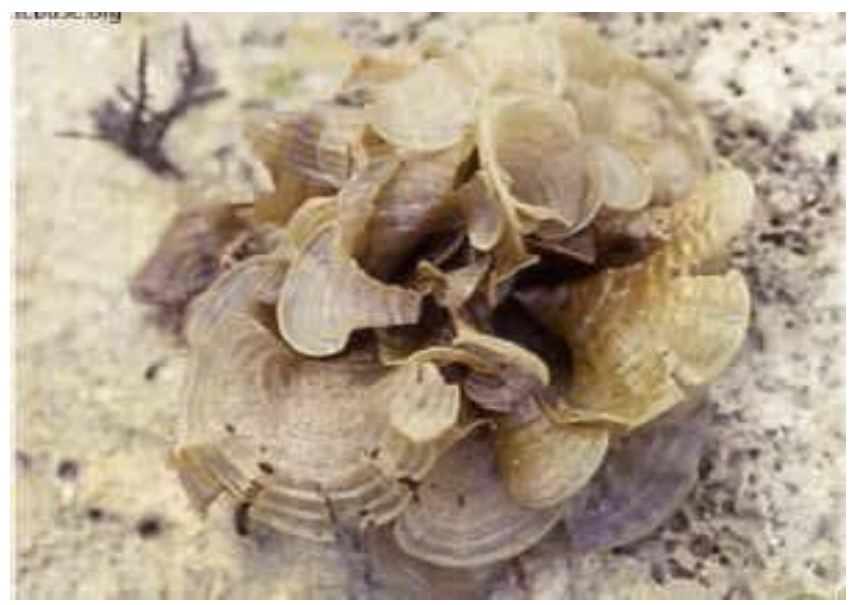

Gambar 1. Padina australis

\section{METODE PENELITIAN}

\section{Lokasi Penelitian}

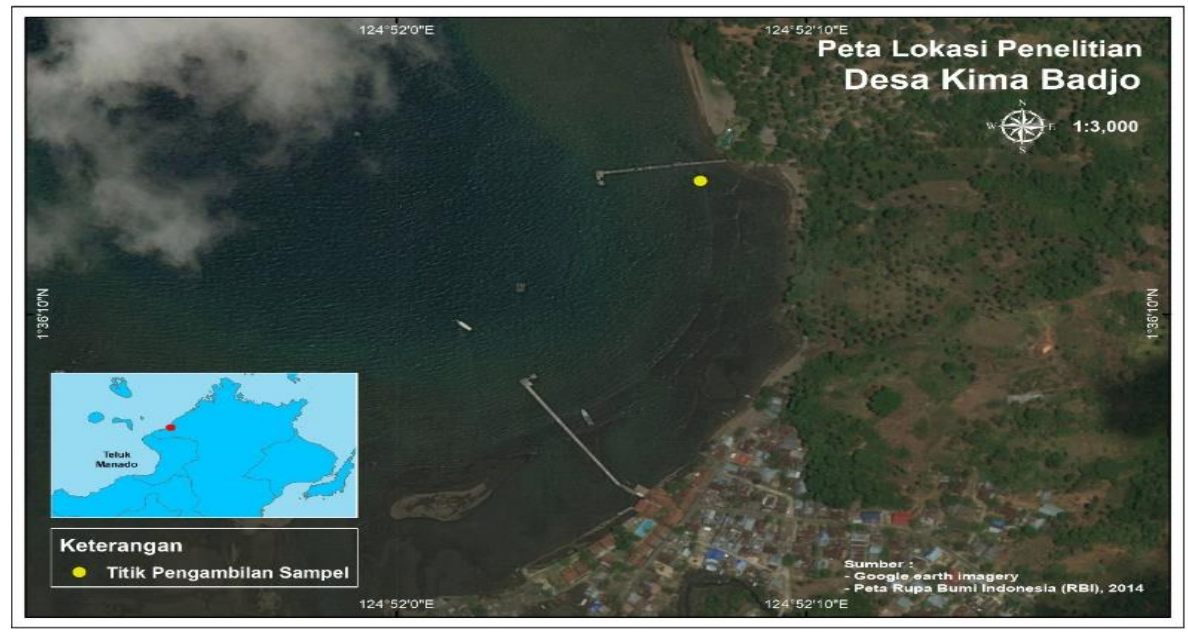

Gambar 2. Peta Lokasi Penelitian di Kima Bajo, Kabupaten Minahasa Utara

Sampel alga Padina australis diambil di perairan Kima Bajo. Perairan ini berjarak 1,9 dengan muara sungai Talawaan Bajo di Kabupaten Minahasa Utara dimana pada hulu sungai ini masih terdapat aktivitas pertambangan skala kecil dengan limbah yang dibuang dibuang ke sungai. Kondisi perairan berwarna cokelat terutama saat musim hujan oleh karena sedimentasi.

\section{Teknik Pengambilan Sampel}

Sampel alga diambil secara langsung pada saat perairan dalam keadaan surut terendah. Sampel diidentifikasi di lokasi dengan menggunakan buku Trono (1997) untuk memastikan spesies $P$. australis. Sampel dimasukan dalam coolbox agar sampel tetap segar dan tidak terkontaminasi dengan bakteri lain, kemudian langsung dibawa ke laboratorium Farmasi FMIPA Unsrat untuk proses analisis sampel.

\section{Isolasi Sampel}

Sampel Alga dipotong dengan ukuran $2 \mathrm{~cm}$, masing-masing diambil 3 potongan alga kemudian dimasukkan ke dalam medium biakan nutrien agar (Media NA) yang sudah diberi perlakuan Arsen $\left(\mathrm{As}_{2} \mathrm{O}_{3}\right)$ dengan konsentrasi 250, 500 dan 1000 ppm). Kemudian diinkubasi pada suhu $37^{\circ} \mathrm{C}$ selama 24 jam. Pengamatan pertumbuhan koloni 
dilakukan dengan menghitung jumlah koloni yang tumbuh.

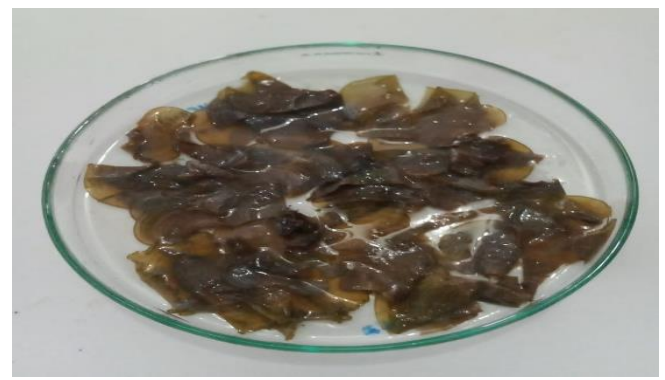

Gambar 3. Sampel Alga

Kemudian diambil satu koloni bakteri dari setiap konsentasi asrsen yang berbeda resisten yang berbeda, diinokulasi lagi pada media NA dalam cawan petri dengan metode goresan T (3 kuadran), diinkubasi selama 1×24 jam dan diamati pertumbuhan koloni bakteri.

Diambil kembali satu koloni bakteri yang berbeda kemudian diinokulasi pada media agar miring secara zig-zag, dilanjutkan dengan inkubasi selama 1x24 jam. Bakteri yang ada pada media agar miring dilakukan uji lanjut,.

\section{Uji Morfologi}

Uji morfologi dilakukan dengan pewarnaan Gram (ljong, 2003) bertujuan untuk menentukan karateristik mikroskopik isolat uji, baik reaksinya

terhadap pewarnaan gram, bentuk sel dan ukurannya.

\section{HASIL DAN PEMBAHASAN}

\section{Lokasi Pengambilan Sampel}

Sampel alga Padina australis diambil di perairan Kima Bajo. Perairan ini berjarak 1,9 dengan muara sungai Talawaan Bajo di Kabupaten Minahasa Utara. Karena lokasi teluk kima bajo berdekatan dengan muara sungai talawaan bajo sehingga perairan ini banyak oleh aktifitas pertambangan emas rakyat. Sisa pengelolaan limbah dibuang ke sungai,

Hasil Pengamatan isolat bakteri yang bertumbuh pada variasi konsentasi Arsen.

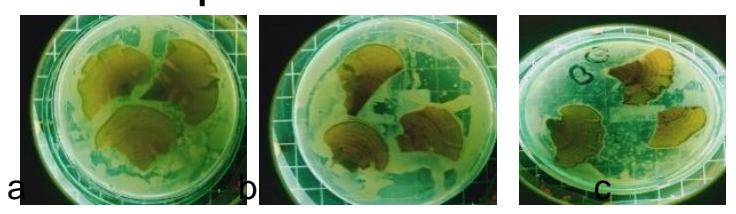

Gambar 4. a). Konsentrasi Arsen 250 ppm kecepatan tumbuh dan kemampuan bertahan hidup isolat tertinggi. b). Konsentrasi Arsen 500 ppm kecepatan tumbuh dan kemampuan bertahan hidup isolat sedang. c). Kecepatan tumbuh dan kemampuan bertahan hidup isolat terendah.

\section{Uji Antibiotik terhadap bakteri resisten Arsen (As)}

Uji resisten antibiotik dilakukan dengan menginokulasi bakteri resisten Arsen pada media seleksi padat Nutrien Agar, kertas disk antibiotik dengan konsentrasi standar beberapa jenis antibiotik yaitu antibiotik cefixime, amoxicillin dan doxycycline diletakkan menggunakan pinset steril pada permukaan media yang sudah diinokulasikan bakteri. Kertas disk antibiotik diatur jaraknya agar tidak terlalu rapat lalu diinkubasi selama 24 jam. Diamati perubahan yang terjadi dan diukur zona beningnya dengan menggunakan jangka sorong (Dwyana, dkk 2012).

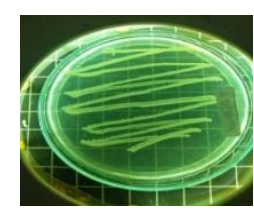

a

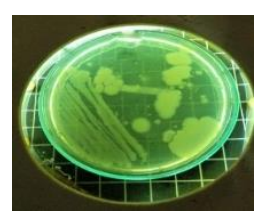

b

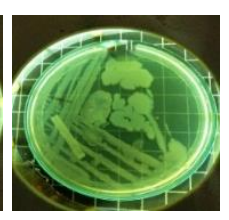

C
Gambar 5. Koloni Bakteri

Pada gambar 5a. terdapat 7 koloni, 5b. 12 koloni dan 5c. terdapat 3 koloni. Pemilihan isolat bakteri didasarkan atas bentuk dan luas permukaan yang tampak pada media NA. Terdapat pertumbuhan bakteri pada cawan petri di setiap konsentrasi, namun koloni yang terbentuk jumlahnya berbeda pada setiap konsentrasi arsen yang di berikan. Pada konsentrasi 250 ppm pertumbuhan koloni masih cukup banyak di permukaan cawan petri. Pada konsentrasi 500 ppm dan 1.000 ppm terdapat penurunan jumlah koloni, terutama pada konsentrasi 1.000 ppm koloni yang terbentuk.

Hasil pengamatan bakteri yang diambil dari 3 (tiga) konsentrasi arsen setelah diinkubasi selama $1 \times 24$ jam untuk pengujian selanjutnya seperti pada Gambar 6. 


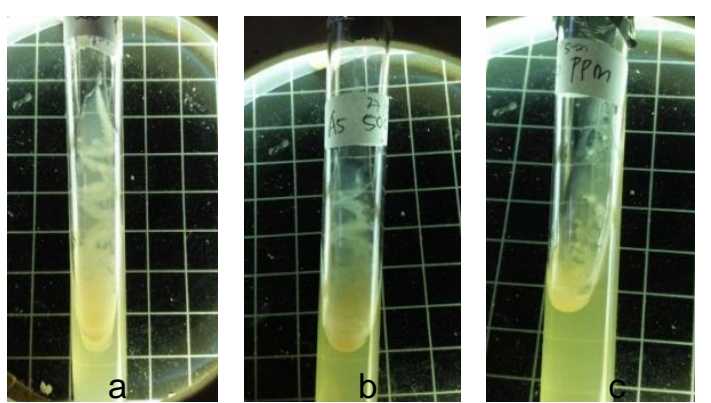

Gambar 6. A) Konsentrasi Arsen 250 ppm, B) Konsentrasi Arsen 500 ppm, C) . Konsentrasi Arsen $1.000 \mathrm{ppm}$

\section{Uji Morfologi}

Uji morfologi untuk melihat karakteristik mikroskopik isolate uji bentuk sel dan ukurannya seperti pada (Gambar 7 dan 8).

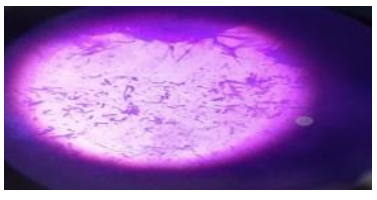

Gambar 7. As 500 ppm Gambar 8.1000 ppm

Hasil pengamatan uji morfologi arsen dengan konsentrasi 500 dan 1.000 ppm menunjukkan warna ungu adalah bakteri Gram positif berbentuk basil. Umumnya bakteri Gram positif adalah bakteri Bacillus sp. yang merupakan genus bakteri basil aerob yang muncul dalam bentuk rantai, dan berukuran 0,5 - 2,5 $\mu \mathrm{m}$. Sebagian besar anggota genus ini adalah organisme sparofit, sering dijumpai pada tanah, air dan udara serta pada vegetasi (Rompis $d k k$, 2018). Menurut penelitian Hidayat $d k k$ (2018), Staphylococcus sp. merupakan bakteri kokus Gram positif. Bakteri yang bersifat non-motil ini dapat tumbuh dalam keadaan anaerob.

\section{Uji Bakteri Resisten Arsen Terhadap Antibiotik.}

Bakteri resisten arsen ini selanjutnya dilakukan uji antibiotik. Berdasarkan pada hasil uji resisten antibiotik pengujian ini menunjukan bahwa pada uji antibiotik amoxicilin dengan zona hambat $0,2 \mathrm{~mm}$ dan antibiotik cefixime dengan zona hambat $0,4 \mathrm{~mm}$ memiliki sifat resistensinya yang aktif melawan bakteri gram positif, sedangkan pada uji antibiotik doxycycline de ngan zona hambat $0,7 \mathrm{~mm}$ aktif melawan bakteri karena lebih hidrolifik sehingga mampu menembus pori dinding bakteri dan aktif pula melawan bakteri gram positif yang tidak menghasilkan B-laktamase. Sedangan pada amoxicillin dan cefixime memiliki sifat atau kemampuan untuk menahan efek antibiotik. Hal ini menunjukan bahwa bakteri dapat merubah diri sedemikian rupa sehingga dapat mengurangi efektifitas suatu obat, bahan kimia ataupun zat lain (Dwyana, 2012).

(a) 500 ppm konsentrasi Arsen dan (b) 100 ditunjukkan pada Gambar 9.
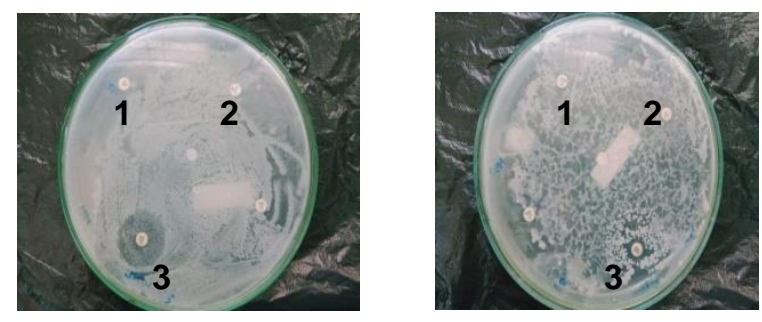

a

b

Gambar 9. Uji Antibiotik

1. Antibiotik Amoxicilin

2. Antibiotik Cefixime

3. Antibiotik Doxycycline

\section{KESIMPULAN}

Berdasarkan hasil penelitian yang dilakukan, makah dapat disimpulkan bahwa:

1) $\mathrm{Uji}$ bakteri resisten arsen dengan konsentrasi 250, 500, dan $1.000 \mathrm{ppm}$ menunjukkan bakteri tetap tumbuh pada media dengan konsentrasi arsen 250 ppm terdapat jumlah koloni 17 $\mathrm{CFU} / \mathrm{ml}$, konsentrasi $500 \mathrm{ppm}$ terdapat jumlah koloni $12 \mathrm{CFU} / \mathrm{ml}$, dan konsentrasi 1.000 ppm terdapat jumlah koloni $3 \mathrm{CFU} / \mathrm{ml}$.

2) Pada konsentrasi arsen 500 ppm dan 1.000 ppm dari hasil pengamatan dari kedua isolat terdapat bakteri Gram Positif dengan bentuk sel basil.

3) Uji antibiotik, dari hasil pengamatan bakteri yang resisten arsen juga resisten terhadap beberapa antibiotik yaitu antibiotik amoxicillin, cefixime, dan doxycycline.

\section{DAFTAR PUSTAKA}


Aslan, L.M. 1998. Budidaya Alga.

Awal, J., H. Tantu., E. K. P. Tenriawaru. 2014. Identifikasi alga (algae) sebagai bioindikator tingkat pencemaran di Sungai Lamasi, Kabupaten Luwu. Jurnal Dinamika.

Baino, I., R. C. Kepel, G. D. Manu. 2019. Biodiversitas makroalga di perairan pesisir Desa Bahoi, Kecamatan Likupang Barat, Kabupaten Minahasa Utara. Jurnal IImiah Platax 7(1): 134141

Dawes J. C. 1998. Marine botany. Second Edition A Wiley Interscience Publication. The United

Dwyana S., Fahruddin. 2012. Uji resistensi antibiotik bakteri resisten $(\mathrm{Hg})$ yang diisolasi dari kawasan pantai Losari Makasar.

Fatimawali, B. J. Kepel, I. Yusuf, N. R. Rosdiana, F. Baharuddin. 2009. Department of Chemistry, Faculty of Medicine, Sam Ratulangi University Manado 2Pascasarjana Hasanuddin University Makassar.

Hidayat, S., D. M. H. Mantiri, J. H. J. Paulus, T. M. Lasut, C. D. N. Rumampuk, S. Undap, A. D. Sumilat. 2021 Accumulation of heavy metal (As, Cd, $\mathrm{Pb}, \mathrm{Hg}$ ) on brown algae Padina australis, cultivated in Kima Bajo Waters, North Minahasa Regency.

Hidayat. I. M., A. Manampiring, J. B. Kepel. 2018. Isolasi dan identifikasi bakteri resisten arsen pada sedimen tanah di pesisir pantai Ratatotok.

Kusumastanto, T. 2011. Pengembangan sumberdaya kelautan dalam memperkokoh perekonomian nasional Abad 21. Tugas Akhir Tidak Diterbitkan. Insitut Pertanian Bogor. Bogor.

Kepel R. C., D. M. H. Mantiri, Nasprianto, 2018a. Biodiversitas makroalga di perairan pesisir Tongkaina, Kota Manado. Jurnal Ilmiah Platax 6(1): 160-173.

Kepel R. C., D. M. H. Mantiri, A. Rumengan, Nasprianto. 2018b. Biodiversitas makroalga di perairan pesisir Blongko, Kecamatan Sinonsayang, Kabupaten Minahasa Selatan. Jurnal IImiah Platax 6(1): 174-187.

Kepel, R. C., D. M. H. Mantiri, D. S. J. Paransa, J. J. H. Paulus, Nasprianto, B. T. Wagey. 2018c. Arsenic content, cell structure, and pigment of Ulva sp. from Totok Bay and Blongko waters, North Sulawesi, Indonesia. AACL Bioflux 3(3): 8
Kepel, R. C., L. J. L. Lumingas, F. N. Pangau. 2001. Kepadatan dan pertumbuhan alga coklat Padina australis Hauck di perairan Desa Blongko, Minahasa. Jurnal Fakultas Perikanan Unsrat 3: 27-32.

Kepel R. C., Lumingas, L. J. L., Watung, P. M. M., Mantiri, D. M. H. 2019a Community structure of seaweeds along the intertidal zone of Mantehage Island, North Sulawesi, Indonesia, AACL Bioflux, 12(1): 87-101.

Kepel R. C., Lumingas, L. J. L., Tombokan J. L., Mantiri D. M. H. 2019b. Biodiversity and community structure of seaweeds in Minahasa Peninsula, North Sulawesi, Indonesia, AACL Bioflux, 12(3): 880-892.

Kepel R. C., Lumingas, L. J. L., Tombokan J. L., Mantiri D. M. H. 2020. Community structure of seaweeds in dry season in Minahasa Peninsula, North Sulawesi, Indonesia, AACL Bioflux, 13(1): 392402.

Kemer, K., D. S. J. Paransa, A. P. Rumengan, D. M. H. Mantiri. 2015. Antibakteri dari beberapa ekstrak pada alga cokelat. Jurnal LPPM Bidang Sains dan Teknologi 2000: 73-81.

Komalig, R. 2006. Analisis kandungan merkuri, arsen dan sianida di air Sungai Talawaan dan Kima Bajo. Skripsi. FMIPA UNSRAT, Manado.

Lay, W. B. 1994. Analisis mikroba di Laboraturium. PT Raja Grafindo Persada. Jakarta.

Mantiri, D. M. H., R. C. Kepel, H. Manoppo, J. J. H. Paulus, D. S. J. Paransa, Nasprianto. 2019. Metals in seawater, sediment and Padina australis (Hauck, 1887) algae in the waters of North Sulawesi. AACL Bioflux 12(3).

Masloman, W. 2005. Analisis kandungan merkuri, arsen, dan sianida di Sungai Talawaan. Skripsi. FMIPA UNSRAT, Manado.

Mpila, D. A. 2012. Uji aktivitas anti bakteri ekstrak etanol daun Mayana (Coleus atropurpureus Benth) terhadap Staphylococcus aereus, Escherichia coli dan Pseudomas aeruginosa secara in vitro. Skripsi. Program Studi Farmasi FMIPA Universitas Sam Ratulangi. Manado.

Puasa, E., D. M. H. Mantiri, A. Rumengan. 2018. Analisis antibakteri alga Padina australis Hauck di perairan Teluk Totok dan perairan Blongko.

Parenrengi, A., R. Syah, E. Suryat. 2010 Budidaya alga penghasil keraginan 
(karaginofit). Balai Riset Perikanan Budidaya Air Payau. Badan Penelitian dan Pengembangan Kelautan dan Perikanan. Kementrian Kelautan dan Perikanan. Jakarta.

Pantow, M. T., J. B. Kepel, Fatmawali. 2018. Isolasi dan identifikasi bakteri resisten arsen pada sedimen di pesisir Laut Buyat.

Rompis, J. T., W. Bodhi, F. Budiarso. 2018. Uj resisten bakteri terhadap arsen yang diisolasi dari sedimen di Muara Sungai Totok.

Rostinawati, E. 2005. Skrinig dan identifikasi bakteri penghasil enzim kitinase dari air laut di perairan Pondok Bali. Penelitian Mandiri, Fakultas Farmasi Universitas Panjajaran Jatinagor.

Sanadi, T. H., J. N. W. Schaduw, S. O. Tilaar, D. M. H. Mantiri, R. Bara, W. Pelle. 2018. Analisis logam berat timbal $(\mathrm{Pb})$ pada akar mangrove di Desa Bahowo dan Desa Talawaan Bajo Kecamatan Tongkaina. Jurnal Pesisir dan Laut Tropis. Vol. 2 No. 1. Manado. 10 hal.

Siahaan, B., D. M. H. Mantiri, J. Rimper. 2017. Analisi logam timbal (Pb) dan konsentrasi klorofil pada alga Padnia australis dari perairan Teluk Blongko, Provinsi Sulawesi Utara.

Sarapi, D., Fatmawali, F. Budiarso. 2014. Identifikasi bakteri resisten merkuri dalam, urine, feses, dan karang gigi pada individu di daerah pesisir pantai Desa Pulisan, Kecamatan Likupang Timur, Kabupaten Minahasa Utara.

Sergiana. 2009. Alga hijau biru. Agro Media Pustaka. Jakarta.

Tulalo, Y. 1999. Analisis pigmen pada beberapa jenis alga mikro. Unpublished Skripsi, FPIK UNSRAT.

Wardhana, A. 2004. Dampak pencemaran lingkungan. Cetakan Keempat. Yogyakarta. Penerbit Andi. 